\title{
AN OVERVIEW OF THE CONSTITUTIONAL FRAMEWORK OF THE RIGHT TO SOCIAL SECURITY WITH SPECIAL REFERENCE TO SOUTH AFRICA
}

\section{CHARLES FOMBAD*}

\section{INTRODUCTION}

Serious efforts to legally recognise and protect human rights in Africa came only with the constitutional reforms that started in the 1990s. Many of the resulting new or revised constitutions now contain provisions aimed at promoting democratic governance, constitutionalism, and respect for the rule of law and human rights. Although many recent studies and surveys show that there have been significant improvements in the quantum of human rights protection in Africa in the last two decades, not much of this research has looked at the specific issue of the right to social security. The aim of this paper is therefore to provide an overview of the position of the right to social security in African constitutions with special reference to the South African constitution and to see what impact this may have in promoting human rights protection. Although this is not generally acknowledged, the right to social security is a human right that is of as much social, economic and political importance as any of the other types of human rights.

The paper will start by briefly looking at the conceptual and contextual framework of the right to social security in Africa. This section will examine the basic concept and definition of social security and consider why it is such an important issue in Africa today. The next section will provide an overview of the constitutional framework for recognising and protecting the right to social security in selected African constitutions. From this overview, it will be seen that South Africa has one of the most constitutionally entrenched frameworks for protecting the right of access to social security on the continent. The main lessons from the South African experience will therefore be considered. This will be followed by a consideration of what the prospects for advancing the right of access to social security rights in Africa are. By way of conclusion, it will be contended that constitutionalism, democracy, good governance and a strong

* Charles Manga Fombad Lic-en-Dt (Un. of Y'de), LLM, PhD (Un. of London), Professor of Law, Institute for International and Comparative Law in Africa (ICLA), Faculty of Law, University of Pretoria. This paper is a revised version of a presentation made at the International Seminar to Mark 20 years of Colombia's 1991 Constitution, in Bogota, Colombia on 13 July 2011. 
ethos for human rights recognition and protection will not easily take root until some of the problems of poverty, deprivation and marginalisation are tackled, ideally through a strong, legally enforceable commitment to social security rights expressly recognised and protected in the constitution.

\section{CONCEPTUAL AND CONTEXTUAL FRAMEWORK OF THE RIGHT TO SOCIAL SECURITY}

Two issues will be briefly considered here. The first is the conceptual framework of the right in an attempt to determine its meaning and possible scope. The second is the contextual framework, which will try to explore why such a right is important for African countries.

\section{A. Conceptual framework of the right to social security}

The concept of social security is fairly flexible and as a result it has been used in widely differing ways not only in the literature on the topic but also across countries and international organisations. Social security has been defined as encompassing both private and public measures (or mixed public-private measures) that are aimed at providing income security to individuals and families who fall victim to particular contingencies such as unemployment, old age, sickness, work injury, invalidity and death. ${ }^{1}$ In some of the literature, social security is distinguished from social protection. Where this is done, social protection is regarded as a broader concept that includes the protection provided between members of the family or members of a local community. ${ }^{2}$ It could also be used in a narrower sense to refer to the measures addressed to the poorest, most vulnerable or excluded members of society. ${ }^{3}$ Sometimes, social protection is used interchangeably with social security. ${ }^{4}$

In a broad sense, social security includes both social insurance and social assistance. Social insurance schemes are programmes that aim to maintain a person's income by providing earnings-related benefits or services in recognition of contributions to an insurance scheme. This may take the form of retirement pensions, disability insurance, survivor benefits and unemployment insurance. Social insurance schemes are by nature collective and their defining characteristic is resource-pooling and risk-sharing with an element of redistribution. They may

1 See M. P. Olivier, N. Smit, G. Mhone and E. R. Kalula (eds), Introduction to Social Security, LexisNexis (2004), p. 13.

2 This is reflected in ILO, World Labour Report 2000: Income Security and Social Protection in a Changing World, ILO (2000), available at http://books.google.co.za/books? $\mathrm{id}=$ fjdseXaqU24C $\&$ printsec $=$ frontcover $\&$ source $=$ gbs_ge_summary_r\&cad= $=0 \# \mathrm{v}=$ onepage $\& q \& \mathrm{f}$ =false (accessed 20 October 2012).

3 ILO, World Social Security Report. Providing Coverage in Times of Crisis and Beyond 2010/2011, ILO Publications (2010), hereinafter referred to as World Social Security Report, available at http://www.ilo.org/public/english/protection/secsoc/downloads/policy/wssr.pdf (accessed 20 October 2012). See also Asian Development Bank, available at http://www.adb.org/ documents/policies/social_protection/appendix.pdf (accessed 20 October 2012).

4 See ILO, World Security Report, supra note 2, p. 13. 
be compulsory or voluntary and may be administered either publicly by the State or privately by insurance companies or by a combination of the two.

Social assistance, on the other hand, involves benefits in kind or in cash, usually funded from general tax revenue, which is provided on the basis of means-testing. Typical examples of this are the so-called safety nets for poor people in need or to cater for contingencies such as interruption of employment, retirement, disability and unemployment. It also includes some universal benefit schemes which are not means-tested such as child and family support. There is also the possibility of a mixed social security system that combines elements of both social assistance and social insurance to take account of the fact that many of the contingencies, such as health, require both social assistance and social insurance measures. ${ }^{5}$

A further distinction is sometimes made in the African context in particular, between indirect and informal social security. Indirect social security refers to certain services, such as those relating to the provision of food and nutrition, water and sanitation, housing, basic education and energy that are not part of the normal traditional social security programme but are nevertheless crucial to enabling people to live a reasonably dignified life. ${ }^{6}$ Informal social security, on the other hand, comprises self-help informal safety-net schemes that are based on membership of a particular social group or community such as family, kinship, age group, neighbourhood, profession, nationality or ethnic group. ${ }^{7}$

From whatever angle social security is looked at, it remains a flexible concept. It involves issues of social protection, and also includes both social insurance and social assistance. The distinction between indirect and informal social security underlines the inherent flexibility of the concept. Although there is no agreement on the elements ${ }^{8}$ that make up social security, those that are considered to be critical and relevant to the right of access to social security are the rights to health, to food, to water, to education and to housing. It is now necessary to examine why these rights are important in the African context.

\section{B. The contextual framework of the right to social security}

One of the things that forced people out of their homes and into the streets in the 1990s was the hardship that decades of civilian and military dictatorship, economic mismanagement and corruption had caused. ${ }^{9}$ African economies were

5 See M. P. Olivier and L. G. Mpedi, Juta's Pocket Companions: Understanding Social Security Law, Juta (2009), p. 9.

6 See L. G. Mpedi, 'Indirect Social Security', in M. P. Olivier, N. Smit and E. Kalula (eds), Social Security: A Legal Analysis, LexisNexis Butterworths (2003), p. 537.

7 Four forms of this discussed by Gsänger are referred to in Olivier and Mpedi, Understanding Social Security Law, supra note 5, pp. 14-15.

8 See the latest ILO extended definition that appears in the World Social Security Report, supra note 3 , p. 20.

9 See further, C. M. Fombad, 'Post 1990 Constitutional Reforms in Africa: A Preliminary Assessment of the Prospects for Constitutional Governance and Constitutionalism', in A. G. Nhema and P. T. Zeleza, The Resolution of African Conflicts, OSSREA and James Currey (2008), pp. 179-99. 
in dire straits. There was rapid inflation; a decrease in real export earnings; a fall in real incomes; a decline in school attendance and the quality of educational systems; a deterioration in health conditions, especially of the poor and vulnerable; widespread unemployment, especially among youths; worsening nutrition and food-security situations; continuing environmental degradation; and an inefficient public sector. ${ }^{10}$ In spite of the sometimes radical constitutional reforms in the last two decades that have seen the recognition and protection of human rights, many of these social problems remain unsolved. ${ }^{11}$ The recent global economic crisis of 2008-9 underscored the importance of addressing social security problems. It showed how countries with effective and efficient social security systems were better equipped to cope with the crisis. ${ }^{12}$

In order to address the social security problematic in Africa, there are numerous issues that have to be tackled. One of the main ones is that of coverage. The general social security coverage in Africa ranges from 5-10 per cent of the total population and in most cases it is limited to wage earners. Most of the economies are agrarian with a majority of the population deriving their income as selfemployed smallholders or operating in the informal economy. In fact, it has been estimated that 70-80 per cent of African workers work in this informal economy. ${ }^{13}$ Since most social security arrangements cover only the formal workers, an overwhelming majority of African workers are unprotected by formal means against the numerous risks that the social security system is designed to protect against such as unemployment, invalidity and old age.

Traditionally, many of these workers in the informal sector depended on collective community-based social security arrangements based on systems of mutual dependence or reciprocity. A vast array of informal membership-based schemes emerged in the 1970s and 1980s to fill the gap left by the State and the markets. These civil society schemes were held together in mutual interest by factors such as kinship or ethnicity, geographical origin or location and friendship. ${ }^{14}$ The best examples of these are the rotating savings and credit associations (ROSCAs). Some were slightly more formal and were organised along cooperative lines, such as the savings and credit cooperatives (SACCOs). For a number of reasons, however, these informal social security systems are fast falling apart, and this has made life quite difficult for a group that is already weak and vulnerable. First, the continuing economic crisis, rising household

\section{Ibid.}

11 See A. Tostensen, 'Feasible Social Security Systems in Africa', 10(2) Development ISSues (2008): 5.

12 See further discussion of this in ISSA, Dynamic Social Security for Africa: An Agenda for Development, ISSA (2008), available at http://www.issa.int/Resources/ISSA-Publications/ Dynamic-Social-Security-for-Africa-An-Agenda-for-Development (accessed 25 October 2012).

13 See for example ILO, 'Pulling Back from the edge of Poverty: Social Security Coverage for All', ILO (2004) available at http://www.ilo.org/global/about-the-ilo/press-and-mediacentre/insight/WCMS_075602/lang-es/index.htm (accessed 20 January 2012).

14 See further S. Devereux, 'Building Social Protection Systems in Southern Africa', available at http://erd.eui.eu/media/BackgroundPapers/Devereaux\%20-\%20BUILDING\%20SOCIAL\%20 PROTECTION\%20SYSTEMS.pdf (accessed 25 October 2012). 
expenditure on items such as education and health care, and high fertility levels have weakened the traditional bonds of kinship within the extended family that made this possible, as people struggle just to find enough to get by on and have little to spare supporting others. Second, revenue from small farm holdings has dwindled due partly to the vagaries of the weather and partly to the fact that these small farm holdings have to be subdivided and shared as the family increases in number from one generation to another. Because of the importance of the informal sector to Africa's development, addressing the social needs of the informal workers is no longer something that African governments can ignore. The AU in fact has taken many serious initiatives in this direction. ${ }^{15}$

Health shocks, such as the HIV/AIDS pandemic, have created such enormous social problems that Africa is still struggling to come to terms with this. Although the rate of new HIV infections has now decreased, Sub-Saharan Africa bears an inordinate share of the global burden. With 22.5 million people living with HIV in 2009, this was 68 per cent of the global total with the most seriously affected countries being Ethiopia, Nigeria, South Africa, Zambia and Zimbabwe. ${ }^{16}$ Generally, the epidemics in Sub-Saharan Africa vary considerably with southern Africa being the most severely affected and Swaziland, with an estimated 25.9 per cent rate of infection in 2009, having the highest adult HIV prevalence in the world. HIV/AIDS has complicated efforts to fight poverty and improve the health situation, especially amongst many vulnerable groups in many ways. First, a majority of those infected and living with HIV/AIDS are women. For example, about 40 per cent of all adult women with HIV live in Southern Africa. Second, the epidemic has diminished the ability of people to support, work and provide for their families. At the same time, treatment and healthcare costs consume a large share of household incomes thereby increasing the cost of living and impoverishing individuals and households. Third, the deepening socio-economic and gender disparities have been accentuated by the epidemic. Women are at high risk of infection and have few options for providing for their families. Children are seriously affected because as a result of their own infection or parental infection, illness or death, they are unable to pursue their education and must leave school to care for ailing parents and younger siblings. Fourth, there is considerable strain on the resources of the community, particularly hospitals, social services, schools and businesses. Healthcare workers, teachers, and business and government leaders have been lost to HIV/AIDS resulting in diminished productivity. Nevertheless, it is the weak response by many African governments to the social, economic and

15 The 8th Ordinary Session of the Labour and Social Affairs Commission of the African Union 11-15 April 2011, Yaounde, LSC/EXP/5(VIII), under the theme: 'Promoting Employment for Social Cohesion and Inclusive Growth'-Social Protection Plan for the Informal Economy and Rural Workers 2011-2015 (SPIRECWORK), available at http://www.au.int/en/sites/default/ files/CONCEPT_NOTE_EN_14_15_APRIL_2011_SA_8TH_ORDINARY_SESSI_LABOUR_

SOCIAL_AFFAIRS_COMMISSION_AFRICAN_UNION_11_15_APR.pdf (accessed $\overline{25}$ October 2012).

16 UNAIDS Report on the Global AIDS Epidemic 2010, UNAIDS (2010), available at http:// www.unaids.org/globalreport/documents/20101123_GlobalReport_full_en.pdf (accessed on 25 October 2012). 
psychological effects of the epidemic that remains a matter of concern. While there is a decline in the rate of infection throughout Sub-Saharan Africa, the plight of those living with the virus remains a problem. The infrastructure, support systems, staff and other resources required to properly monitor and implement prevention and treatment programmes remain inadequate. The UNAIDS Global Report of 2010, in a survey of fourteen countries with the highest HIV prevalence rate in Africa, shows that only two of them, Congo and Uganda, are able to perform above median in the domestic investment priority index (DIPI). ${ }^{17}$ The UNAIDS DIPI attempts to measure the extent of investment priority given by governments to support their national AIDS response. With a median level of priority of 0.35 , the UNAIDS survey shows that eight out of the fourteen countries appear to be spending less on the AIDS response than might be expected from them given the disease burden and government resources. This is not surprising for it has been estimated that African countries on average spend only 4.3 per cent of their GDP on social security as compared with 25 per cent in Europe and 16.6 per cent in North America. ${ }^{18}$

No region in the world appears to endure so much disparity between people's rights and their realisation as Africa does. Although population ageing is one of humanity's success stories, ${ }^{19}$ this creates long-term challenges for social security programmes in Africa. Very few people expect a pension in their old age. Yet, by 2050 , the number of older women and men on the continent will rise to over 200 million, which is about 10 per cent of the estimated population of 2 billion people. ${ }^{20}$ Certainly, the challenges that lie ahead are enormous. The first and most important step will be for African states to recognise the fact that the only way to strengthen social safety nets and reduce vulnerability shocks is for the State to recognise access to social security as a constitutional right to which all are entitled. We therefore need to examine the present position taken under the different African constitutions.

\section{OVERVIEW OF THE RIGHT TO SOCIAL SECURITY IN SELECTED AFRICAN CONSTITUTIONS}

If the severe backlogs in the delivery of social security rights in Africa have to be met, then a new approach that entails entrenching these rights in national

17 The DIPI for Congo is 0.68 and that for Uganda is 0.72 . The DIPI for the other countries covered in the study is as follows: Botswana, 0.31; Cameroon, 0.06; Côte d'Ivoire, 0.05; DR Congo, 0.28; Ghana, 0.10; Kenya, 0.33; Lesotho, 0.33; Malawi, 0.03; Mozambique, 0.03; Nigeria, 0.13; South Africa, 0.18; and Zimbabwe, 0.04. See UNAIDS Report, supra note 16, p. 148.

18 See ISSA, Social Policy Highlight 07, ISSA (2007), available at http://www.iss.int (accessed 20 January 2012).

19 South East Asian Conference on Ageing: Improving Well Being in Later Life, 17-18 July 2010, available at http://seaca2010.files.wordpress.com/2010/03/seaca2010-flyer-tentativeprogram1.pdf (accessed 25 October 2012).

20 See 'Total African Continent Population 1950-2050 (UN Estimates)', available at http:// www.blatantworld.com/feature/africa/total_continent_population_1950_to_2050.html (accessed 25 October 2012). 
constitutions is necessary. This rights-based constitutional approach finds its basis in many international and regional agreements and treaties to which many African states are parties. This approach entails two critical elements: first, a rightsbased element, which has a number of important components; and second, the constitutionalisation of this right, which, as will be shown in a later section using the example of South Africa, strengthens the normative value of social security as a right.

The rights-based approach to human rights in general has been defined by various authors in different ways. ${ }^{21}$ L.-H. Piron in her discussion of rightsbased approaches to social protection identifies several features which are equally applicable to social security rights. In essence, the rights-based approach may have the following implications: $:^{22}$

1. that social security should be considered as a right and entitlement and not just a matter of charity;

2. that there is an obligation on states to recognise, guarantee and protect social security;

3. that a range of human rights principles can be used as basis to enforce social security;

4. that citizens can claim and enforce their entitlement to social security;

5. that a range of international human rights principles can be used to justify the right to social security; and

6. that certain core obligations and minimum standards may be expected in assessing the compliance with the obligation to provide social security.

Support for this rights-based approach to social security rights can be found in a number of important international treaties and conventions.

\section{A. International basis for a rights-based approach to the social security obligation of states}

The right to social protection by states should no longer be regarded merely as a matter of charity or generosity that a state could implement at its convenience, but a basic responsibility that has its normative foundation in international law and in a number of international and regional treaties and conventions. African countries are parties to most of these treaties and conventions.

The human rights dimension of social security was present in the International Labour Organization (ILO) Declaration of Philadelphia of 1944 which called for the 'extension of social security measures to provide a basic income to all in need

21 See for example L.-H. Piron, 'Rights-based Approaches to Social Protection', available at http://www.gsdrc.org/go/display/document/legacyid/1617 (accessed 25 October 2012); and S. Buentas and S. Beales, 'Claiming Citizen's Rights', 13(8) Ageing and Development (2003): 8 (accessed 20 January 2012).

22 Piron, 'Rights-based Approaches to Social Protection', ibid., p. 3. 
of such protection and comprehensive care' ${ }^{23}$ In many respects, however, it may be said that the real normative basis of the right to social security can be traced to the very foundational document of international human rights, the Universal Declaration of Human Rights (UDHR) of 1948. Its article 22 declares that

everyone, as a member of society, has the right to social security and is entitled to realisation, through national effort and international cooperation and in accordance with the organisation and resources of each state, of the economic, social and cultural rights indispensable for his dignity and the free development of his personality.

Another important provision is article 25(2), which states that

everyone has a right to a standard of living adequate for the health and well-being of himself and of his family, including food, clothing, housing and medical care and necessary social services, and the right to security in the event of unemployment, sickness, disability, widowhood, old age or other lack of livelihood in circumstances beyond his control.

The UDHR also provides that motherhood and childhood are entitled to special assistance and protection ${ }^{24}$ and guarantees a right to education. ${ }^{25}$ Although the UDHR, as its name suggests, is not a treaty and thus not binding, it has come to occupy a special status amongst international human rights instruments. Over the years, as a result of the fact that its provisions have been extensively incorporated into numerous international and regional instruments as well as national constitutions and there have been numerous affirmations of its special status in judicial decisions, there is no longer any doubt that the principles contained in the UDHR are rules of customary international human rights law. ${ }^{26}$ One can therefore argue that a party can rely on most of the provisions of the UDHR as customary international human rights law that are ipso facto directly applicable in common law jurisdictions as part of national law. ${ }^{27}$

The right to social security is also recognised in the 1966 International Covenant on Economic, Social and Cultural Rights (ICESCR). Article 9 provides that ' $[S]$ tates parties to the present covenant recognise the right of everyone to social security, including social insurance.' In its articles 10-13, it recognises a myriad of other associated rights.

23 Section III(f) of the Declaration Concerning the Aims and Purposes of the International Labour Organization (ILO), annex to the Constitution of the ILO.

24 See article 25(2) of the UDHR.

25 See article 26 of the UDHR.

26 See the discussion by H. Waldock, 'Human Rights in Contemporary International Law and the Significance of the European Convention', 11 International and Comparative Law Quarterly (1965): 15 .

27 See I. Brownlie, Principles of Public International Law, 6th edn, Oxford University Press (2003), p. 41; and J. Dugard, International Law. A South African Perspective, 3rd edn, Juta (2005), p. 52. 
The ICESCR has 48 African state parties but surprisingly South Africa and other countries like São Tomé and Príncipe and the Comoros are not parties. ${ }^{28}$ The obligations imposed by the ICESCR are monitored through the state reporting procedure provided for under articles 16 and 17. The Committee on Economic, Social and Cultural Rights was established in 1985 to monitor the implementation of the ICESCR. Unlike the other five human rights treaty bodies,${ }^{29}$ this Committee was not established by its corresponding instrument but rather by the Economic and Social Council (ECOSOC) of the UN. It has adopted a variety of means to monitor the implementation of the Covenant and to see how its implementation and enforcement by states can be improved. One of the strategies adopted in 1988 was the preparation of 'general comments' on the rights and provisions contained in the Covenant with a view to assisting state parties in fulfilling some of their obligations under the Covenant and providing interpretative clarity as to the intent, meaning and content of the Covenant. On 23 November 2007, it adopted General Comment No. 19 on the right to social security. ${ }^{30}$ The Committee expressed its concern at the very low levels of access to social security with a large majority (about 80 per cent) of the global population currently lacking access to formal social security and with 20 per cent of this majority living in extreme poverty. The Comment tried to define the normative content of the right to social security. It points out that the right to social security includes the right not to be subject to arbitrary and unreasonable restrictions of existing social security coverage, whether obtained publicly or privately. It points out that the social security system should provide coverage for nine principal branches of social security, which it identifies as consisting of: health care, sickness, old age, unemployment, employment injury, family and child support, maternity, disability, and survivors and orphans. The Comment also points out that the right to social security, like any human right, imposes three main obligations on states: the obligation to respect, the obligation to protect and the obligation to fulfil, and requires states to develop national strategies for the full implementation of this right. It lists a number of core obligations that states are under a duty to fulfil, and contains one of the clearest indications of the normative content of the right to social security, the nature of the obligation that is imposed on states by the Covenant and the various steps that States can take to progressively implement this right. ${ }^{31}$

28 Status at 28 June 2011, available at http://treaties.un.org/Pages/ViewDetails.aspx? chapter=4\&lang=en\&mtdsg_no=IV-3\&src=TREATY (accessed 26 October 2012).

29 These are: (1) Human Rights Committee (CCPR) - International Covenant on Civil and Political Rights and its optional protocols; (2) Committee on the Elimination of Racial Discrimination (CERD) - International Convention on the Elimination of All Forms of Racial Discrimination; (3) Committee on the Elimination of Discrimination Against Women (CEDAW) - Convention on the Elimination of All Forms of Discrimination against Women and its optional protocol; (4) Committee Against Torture (CAT)-Convention against Torture and Other Cruel, Inhuman or Degrading Treatment; and (5) Subcommittee on Prevention of Torture (SPT) - Optional Protocol to Convention against Torture.

30 See Committee on Economic, Social and Cultural Rights, 39th Session, 5-23 November 2007, GE.08-40397 (E) 070208.

31 Ibid. 
The right to social security was subsequently incorporated into a myriad of other international human rights treaties ${ }^{32}$ and regional human rights treaties. ${ }^{33}$ Besides the ICESCR, the other very significant contribution to the development of the right to social security has come from the International Labour Organization (ILO), one of the specialised agencies of the UN. The achievement of social security for all is at the core of the ILO's constitution and mandate. The ILO promotes a rights-based approach to social security with ILO standards being used as the principal means of action for assisting member states towards the realisation of this right. It has done this by adopting conventions and recommendations on social security which lay down obligations and guidelines for states. It has adopted more than thirty-one conventions and twenty-three recommendations, which lay down international standards. These have greatly contributed to the development of international social security law and to the definition of the human right to social security. It is worth noting, however, that the ILO is principally concerned with social protection associated with employment. This limits its relevance for developing countries, such as those in Africa, where the number of risks and vulnerabilities are not associated with employment and income. Although the ILO's approach to social security is limited mostly to income security, it is now moving towards a more comprehensive approach that will make it more relevant to African countries.

At a regional level, the main African instrument, the African Charter on Human and Peoples' Rights of 1981, does not specifically recognise the right to social security. Nevertheless, there are several provisions that recognise the right to benefit from various types of social security-related rights. ${ }^{34}$ The Constitutive Act of the AU also does not specifically mention the right to social security but deals with this indirectly in both its objectives ${ }^{35}$ and guiding principles. ${ }^{36}$ The AU's agenda on social security issues has been driven by the Labour and Social Affairs Commission. In 2004, the AU adopted the Ouagadougou Plan of Action on Employment Promotion and Poverty Alleviation with the key priority being to improve and strengthen the social protection schemes and extending

32 See article 5(e)(iv) of the International Convention on the Elimination of All Forms of Racial Discrimination; articles 11, para. 1(e) and 14, para. 2(c) of the Convention on the Elimination of All Forms of Discrimination Against Women; and article 26 of the Convention on the Rights of the Child.

33 See article XVI of the American Declaration of the Rights and Duties of Man; article 9 of the Additional Protocol to the American Convention on Human Rights in the Area of Economic Social and Cultural Rights (Protocol of San Salvador); and articles 12-14 of the European Social Charter. The African regional human rights treaties are discussed below.

34 For example, article 15 provides for a right to work under equitable conditions; article 16 for the right to enjoy the best attainable state of physical and mental health; article 17 to the right to education; article 18(1)\&(2) obliges states to protect the family; and article 18(4) requires states to provide special measures to protect the aged and disabled.

35 See for example, in its objectives as stated in article $3(\mathrm{k})$, the desire to raise the living standards of African peoples and in article 3(n) to work towards the eradication of preventable diseases and promotion of good health.

36 Amongst these principles are in article 4(l) the promotion of gender equality, article 4(m) the respect for human rights and article 4(n) the promotion of social justice. 
them to the informal sector of the economy. ${ }^{37}$ In 2008, the AU developed a Social Policy Framework (SPF) for Africa, which reiterates the strategies of the Ouagadougou Plan of Action. ${ }^{38}$ The SPF focuses on eighteen thematic social issues, which include social protection, health, HIV/AIDS, TB, malaria and other infectious diseases, education, food and nutrition, the family, children, adolescents and youth, ageing, disability, and gender equality and women's empowerment. The principle of social protection is given prominence and the broad range of recommended actions is outlined to guide member states in formulating and implementing their own social policies. There are numerous other conventions, declarations and statements both at the continental level, such as the African Charter on the Rights and Welfare of the Child 1999, and at regional level. For example, within the Southern African Development Community (SADC), there are important instruments dealing with social security rights, such as the Charter of Fundamental Social Rights in SADC, the Code on Social Security in the SADC, the Declaration on HIV/AIDS and the Protocol on Health. ${ }^{39}$

There are thus a plethora of binding and non-binding international human rights instruments which have been signed by African states committing them to recognise, respect, protect, and promote the right to social security. Where these instruments are of a non-binding nature, like declarations and recommendations, they might not be strictly binding nevertheless they are usually indicative of the will of States. As the International Court of Justice pointed out in the North Sea Continental Shelf Case (the Netherlands $v$ Germany) and (Denmark v Germany) ${ }^{40}$ the standards contained in such non-binding instruments may attain the status of customary international law if they are repeated in state practice. Where however it is a binding international human rights instrument, unless where it merely affirms principles of customary international law, it will have domestic effect only when it is directly or indirectly domesticated. Most of the international human rights principles, such as the right to social security have been domesticated in the Bill of Rights or provisions dealing with human rights protection in African constitutions. It is now necessary to examine how exactly this has been done.

\section{B. The scope of the right to social security in selected African constitutions}

The constitutional entrenchment of the right to social security, while not being the only means of recognising, protecting and enforcing this right, is certainly the best way to do this. As will shortly be shown, using the example of South Africa, this will not only put pressure on the State to enforce this right but also ensures

37 See EXT/ASSEMBLY/AU/4 (III).

38 For this document, see http://bravo.ilo.org/gimi/gess/RessShowRessource.do;jsessionid=4e5b1 e70c36f30da63f2abe30ea69520bd5563204824456145aef84d0f04f7fd.e3aTbhuLbNmSe34Pbxq QaxqMa310? ressourceId=22987\&longTitle=Social+Policy+Framework+for+Africa $+\&$ author $=$ African+Union\&ressYear=2008 (accessed 26 October 2012).

39 Available at http://www.sadc.int/index/browse/page/32 (accessed 26 October 2012).

40 ICJ Reports 1953, 44. 
that it does not arbitrarily enact legislation that undermines this right. Perhaps the most important thing that can be said here about the South African approach based on its 1996 constitution is the fact that it successfully debunks the myth about the non-justiciability of socio-economic rights such as the right to social security.

Table 1 shows to what extent the right to social security has been incorporated in African constitutions. The choice of countries used has been informed by a number of considerations. First, the need to select countries that represent the two main constitutional cultures that have influenced modern African constitutions, namely, the English Westminster constitutional culture, which in many instances has been mixed with elements of the American presidential system and has been widely copied in anglophone Africa; and the French 1958 Fifth Republic or Gaullist system that has been copied in francophone Africa and to some extent influenced the systems in lusophone Africa. In this regard, an old Westminster model constitution like that of Botswana of 1966 as well as a more modern version such as the 1999 Nigerian constitution are analysed. The Cameroon constitution of 1996 is used as a typical example of an old-style Gaullist 1958 constitution and the Benin constitution as a modern version of this constitutional model. The 1996 South African constitution is included as setting the modern pace in dealing with socio-economic rights generally while the most recent constitutions, the 2010 constitutions of Angola (a lusophone country) and Kenya, are included. The present constitutions of some Arab countries are considered although the present uprising or so-called Arab Spring is likely going to result in a fundamental revision of many of these constitutions. In all, thirty constitutions are analysed.

The analysis itself is divided into three main parts. The first column determines whether there is recognition of a general right of social security. The second column tries to determine whether in spite of the recognition or non-recognition of a right of social security, a number of specific essential benefits that are associated with the right to social security are recognised. The third column deals with the all-important issue of justiciability and tries to ascertain whether these rights are justiciable.

The right to social security as a distinct right is specified in fourteen out of the thirty constitutions examined; however, it is only in two of these, the 1996 South African constitution (as will be shown below) and the 2010 Kenyan constitution (see article 43) that this and related rights are specified in depth. The Ethiopian, Nigerian and Ugandan constitutions also cover a number of these rights but, as will shortly be seen, in the absence of a legally binding obligation on the State to enforce them, they may not be as effective as one would expect.

None of the constitutions examined recognises and protects all the other rights usually associated with the right to social security. The two oldest constitutions, the Botswana constitution of 1966 and the Mauritius constitution of 1968, hardly have any provisions dealing with social security rights at all. In fact, the only provision in the later constitution is section 17A, which ironically deals with retirement benefits for members of parliament. All the constitutions, with the 


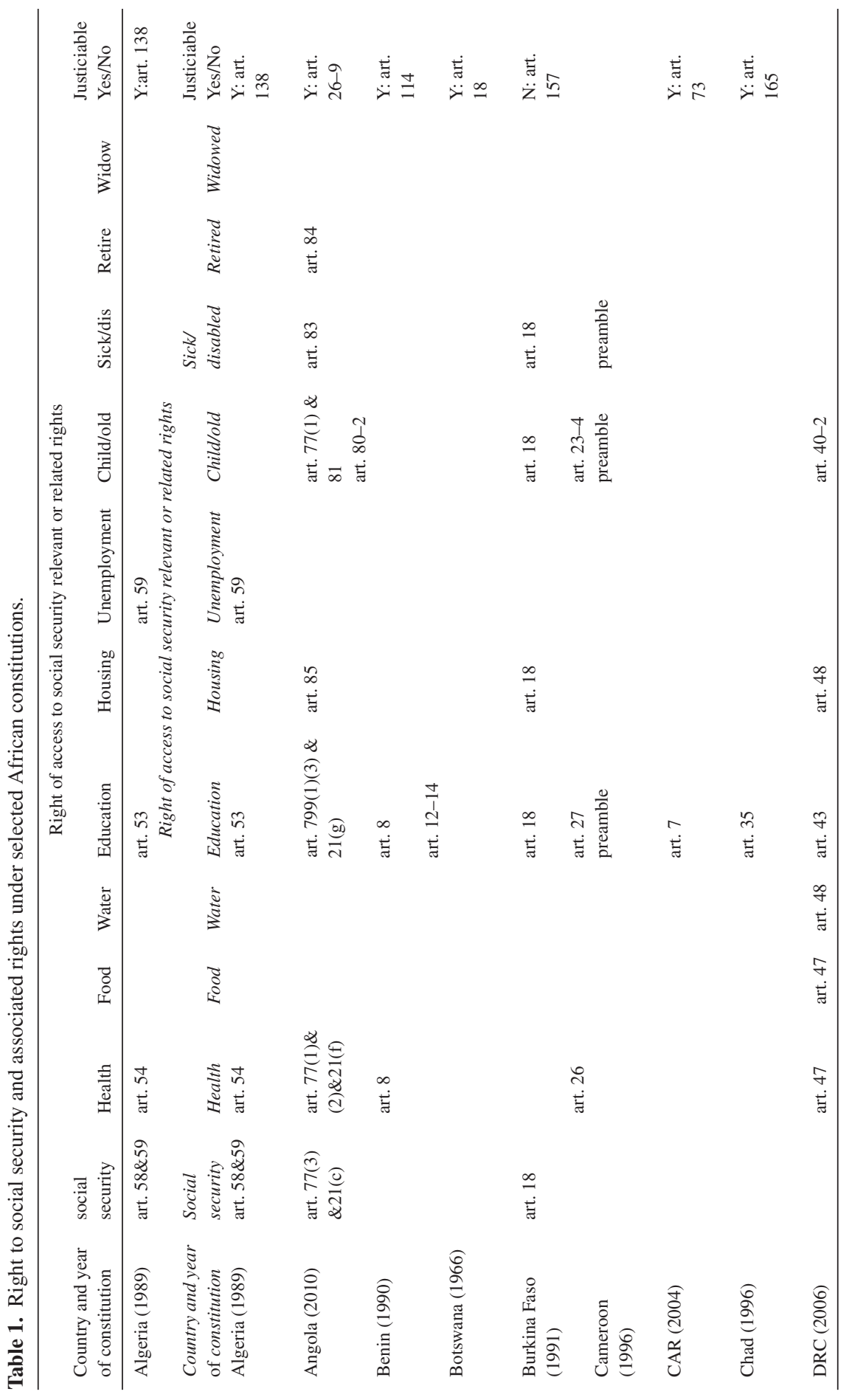




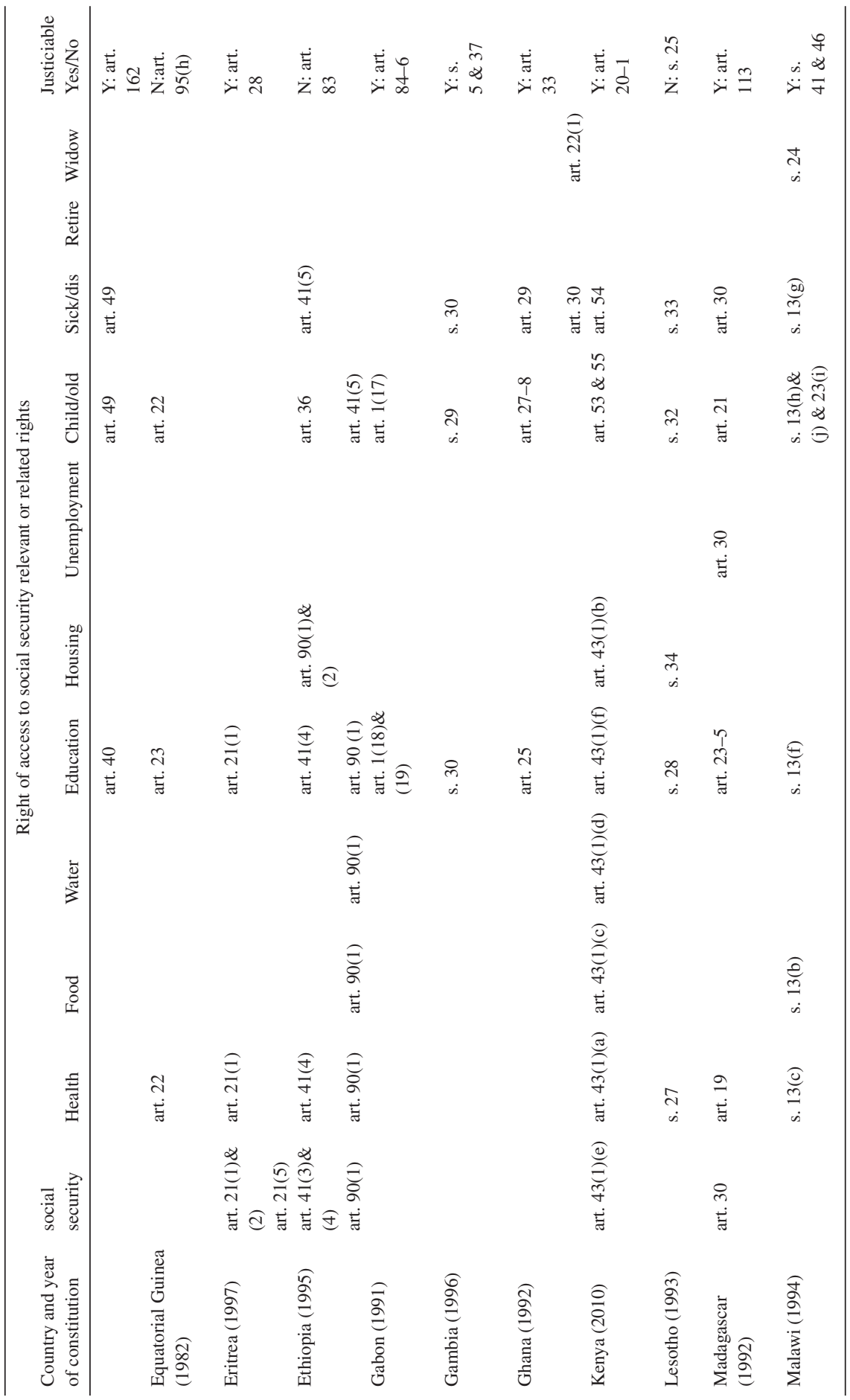




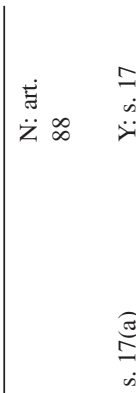

$\infty$

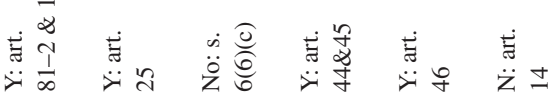

$\dot{\infty}$ 范

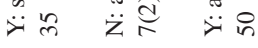

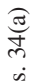

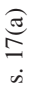

$\underset{\substack{\overparen{d} \\ \stackrel{0}{\infty}}}{\dot{m}}$

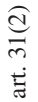

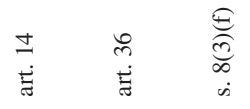

is

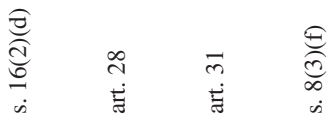

$\frac{\sum}{i}$

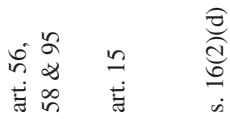

仓ิ

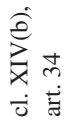

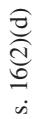

$\stackrel{\infty}{\stackrel{\infty}{\infty}}$

خे

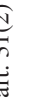

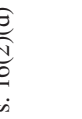

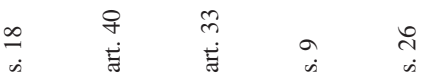

च.

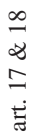

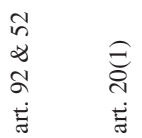

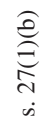

$\begin{array}{ll}\dot{x} & 0 \\ \dot{x} & 0 \\ \dot{0} & \dot{\Xi}\end{array}$

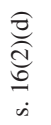

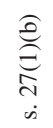

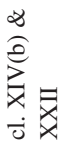

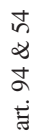

$\frac{\overparen{0}}{\stackrel{0}{(}}$

$\begin{array}{ll}\text { ซ } & \text { กิ }\end{array}$

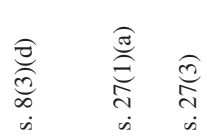

$\infty$
$e$
$e$
$i$
$i$
$x$

三

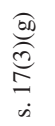

in

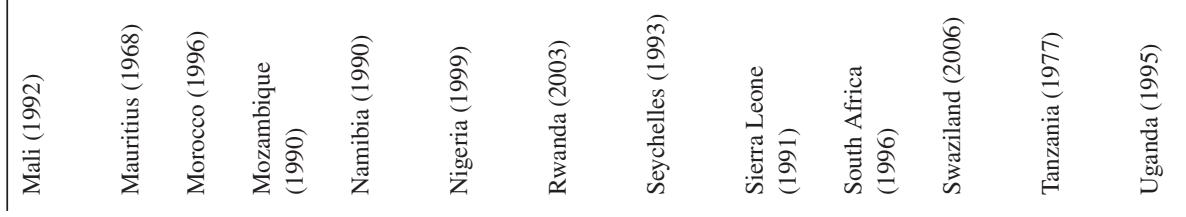


obvious exception of these two, have provisions providing for a right to education. What is perhaps remarkable is the fact that in almost all francophone African constitutions, there is provision for a right to free education. ${ }^{41}$ Many of these constitutions try to deal with peculiar problems of each country, such as the legacy of apartheid in Namibia and South Africa ${ }^{42}$ and the aftermaths of genocide in Rwanda. For example, article 14 of the Rwandan constitution was amended in August 2008 to deal specifically with the legacy of genocide.

No matter how elaborate and comprehensive the provisions guaranteeing a right to social security may be, it will serve no purpose if they cannot be enforced or can be violated without any legal remedies or consequences. The issue of justiciability has been one of the most contentious issues in the discourse on socioeconomic rights in general. ${ }^{43}$ The right to social security can be meaningful and effective only if there is a mechanism provided, ideally in the constitution, for ensuring that it can be enforced and violations of it sanctioned. In many instances, the mechanism for reviewing violations of the right to social security coincides with the mechanism for reviewing and controlling the constitutionality of laws generally. From the perspective of justiciability, there are two main patterns that can be observed in the thirty countries covered in this study.

The first pattern consists of those constitutions that expressly or implicitly make all matters relating to socio-economic rights non-justiciable. Thus the constitutions of a number of countries such as Lesotho, ${ }^{44}$ Nigeria, ${ }^{45}$ Sierra Leone ${ }^{46}$ and Tanzania ${ }^{47}$ place the right to social security and related rights under a section with labels such as 'fundamental objectives and directive principles of state policy' or 'principles of state policy', which are expressly stated not to be enforceable by the courts. In two other cases, that of Cameroon and Uganda, many of the social security-related rights provided for in these constitutions are not legally enforceable because they appear only in the preamble to the constitution. In most of the francophone constitutions, the non-enforceability of the right to social security is essentially the result of the ineffective mechanism provided for enforcing them before the courts. Under these constitutions, a violation of constitutional rights, a typical example of which is socio-economic rights, can be reviewed only by a quasi-administrative/quasi-judicial body

41 See article 7 of the constitution of the Central African Republic; article 35 of the constitution of Chad; article 45 of the constitution of the DR Congo; article 1(18)\&(19) of the constitution of Gabon; and articles 17-18 of the constitution of Mali. The constitution of Equatorial Guinea also recognises the right to free education in article 23 and The Gambia is one of the few anglophone African countries that recognises a right to free education in section 30 of its constitution.

42 See the preamble to both constitutions.

43 See for example K. Tomasveski, 'Justiciability of ESC Rights', International Criminal Justice Review (1995): 203-19; and M. Tushnet, 'Social Welfare Rights and the Forms of Judicial Review', 82 Texas Law Review (2004): 1895-919.

44 See section 25 of the constitution.

45 See sections 6(6)(c) and(9)(3) of the constitution.

46 See section 14 of the constitution.

47 See section 7(2) of the constitution. 
called the Constitutional Council. ${ }^{48}$ The Constitutional Council model-which is usually associated with Continental Europe and more specifically, the Conseil Constitutionnel of the French Fifth Republic Constitution of 1958-was widely adopted in the constitutions of francophone African countries before the 1990s. From a functional and substantive perspective, the main defect of this model is its quasi-administrative rather than judicial nature. Composed as it is of political appointees who are not necessarily judges, this compromises the chances of effective review. Perhaps the fatal flaw in this system of review is the fact that it can only be seised by the very politicians who are apt to make unconstitutional laws and often mainly with abstract pre-promulgation review, which renders the whole mechanism potentially irrelevant and unreal. Even the potentially broad range of social security rights provided in the recent Angolan constitution are compromised by the fact that ordinary citizens cannot, because of locus standi restrictions imposed by article 230 of the constitution, legally compel the government to implement these rights or challenge it when the rights are violated by the government.

The second pattern consists of those countries that allow disputes relating to the right to social security, like any other dispute involving the rights provided for in the Bill of Rights or provisions dealing with human rights to be brought before the courts. In most anglophone African constitutions it is provided that any person alleging that any provision in the Bill of Rights has been, is being or is likely to be violated by any person anywhere, may institute proceedings for redress in the High Court. The High Court is given flexible powers when dealing with such violations. ${ }^{49}$ The problem of effectiveness of social security rights, however, like that with all other socio-economic rights, goes beyond merely allowing courts to adjudicate disputes in these areas. Because of the numerous policy implications that these disputes entail, clear constitutional implementation guidelines have become the norm. This was the approach adopted in the South African constitution. It did not merely recognise and affirm the principle that everyone has the right to have access to social security but went further to state in section 27(2) that ' $[\mathrm{t}]$ he State must take reasonable legislative and other measures within its available resources, to achieve the progressive realisation of each of these rights.' It therefore attempted to define the nature of the State's obligation. The new Kenyan constitution takes this further. Like the South African constitution, it states in article 21(2) that '[t]he State shall take legislative, policy and other measures, including the setting of standards, to achieve the progressive realisation of the rights guaranteed under Article 43.' It reserves such disputes to the High Court and also provides a wide range of possible remedies ${ }^{50}$ but perhaps the major innovation is the expansion of the rules of locus standi in article

48 See for example article 157 of the constitution of Burkina Faso; article 47(2) of the Cameroonian constitution; article $95(\mathrm{~h})$ of the constitution of Equatorial Guinea; and article 83 of the constitution of Ethiopia.

49 See for example section 18 of the Botswana constitution; article 33 of the constitution of Ghana; sections 5 and 37 of the constitution of Gambia; and section 17 of the constitution of Mauritius.

50 See articles 23 and 165(3)(b). 
22(2) ${ }^{51}$ Article 22(3) even goes further to limit formalities relating to proceedings to a minimum. ${ }^{52}$ This is of tremendous importance given that a major obstacle to the effective enforcement of human rights in many African countries is the fact that too many people, whose constitutionally protected human rights have been violated, due to ignorance, poverty, marginalisation or some other social or economic disadvantage, are unable to approach the courts for relief. ${ }^{53}$ Broadening the locus standi access to justice in this way will considerably help to alleviate the situation of the poor, who are often the main victims of human rights abuses.

Generally, litigants are often only provided with a remedy when the authorities violate or threaten to violate the constitution but now under some constitutions, they may even take action where the alleged 'violation' consists of a failure to fulfil a constitutional obligation. This may result in a declaration of unconstitutionality for the omission to carry out a constitutional obligation. ${ }^{54}$ It is a welcome development on a continent where the executives and legislatures are well noted for regularly ignoring the implementation of constitutional provisions. This unique remedy is probably designed to cajole or force these two branches to fulfil their constitutional obligations and for the first time guarantees that compliance with constitutional obligations is not a matter that lies within the exclusive and absolute discretion of these two branches. More mandatory language is used by the Kenyan constitution when it states in article 21(4) that the 'state shall enact and implement legislation to fulfil its international obligations in respect of human rights and fundamental freedoms'. Although article 232 of the Angolan constitution appears to go further by expressly providing, under the heading 'unconstitutionality by omission', that the Constitutional Court may be requested to rule on unconstitutionality by omission, the fact that the locus standi to request such a ruling has been vested exclusively on 'the President of the Republic, one fifth of the members [of the National Assembly] in full exercise of their office and the Attorney-General' renders this process illusory. These are the very people who are supposed to make these laws and can hardly be expected to take action against themselves for doing nothing!

The right to an effective and efficient remedy does not necessarily require a review only by a court of law. Nevertheless, it is imperative that the remedy provided be effective. From this perspective, the resolution of disputes through a quasi-administrative body whose composition is determined wholly or partly

51 This has been achieved in countries such as India largely through a process of judicial activism. See V. Sripati, 'Constitutionalism in India and South Africa: A Comparative Study from a Human Rights Perspective', 16 Tulane Journal of International and Comparative Law (2007): 49.

52 The new Angolan constitution in articles 73-5 also appears to broaden the rules of locus standi but articles 228 and 230, which restrict access to certain specified personalities, cast serious doubts about the effectiveness of this.

53 Here again the Kenyans learned from the epistolary or open-letter jurisdiction approach developed by the Indian courts. See P. N. Bhagwati, 'Social Action Litigation: The Indian Experience', in N. Tiruchelvam and R. Coomaraswamy (eds), The Role of the Judiciary in Plural Societies, Palgrave Macmillan (1987), pp. 20-1.

54 See G. Mendes, 'Constitutional Jurisdiction in Brazil: The Problem of Unconstitutional Legislative Omission' (2008), available at http://www.stf.jus.br/repositorio/cms/portalStfInternacional/ portalStfDiscurso_en_US/anexo/Omisao_Legislativa_v_Ing.pdf (accessed 27 October 2012). 
by politicians compromises the chances of ensuring that the constitution is not violated. If it is accepted as legitimate to establish in a constitution certain guarantees designed to protect citizens as well as control the government as to what to do or not do, then it must also be considered as legitimate to build into the constitution the measures necessary to ensure that the guarantees contained in it are respected. Perhaps one of the major surprises and disappointments with the new Angolan constitution, which probably contains the most elaborate provisions on social security rights in any constitution on the continent, ${ }^{55}$ is the very weak and uncertain mechanism it provides for enforcing these rights.

Some of these constitutions make references to international human rights instruments and the question here is whether this has any impact on their effectiveness in protecting social security rights. For example, the preamble to the Cameroonian constitution 'affirm[s]' its attachment to the fundamental freedoms enshrined in the UDHR, the UN Charter, the ACHPR 'and all duly ratified international conventions relating thereto'. This, it is submitted, does not render any of these instruments part of national law nor can they on this basis alone be invoked in the interpretation of the constitution. Far more significant is the Beninese constitution, which in its preamble refers to these international instruments and states that their provisions 'make up an integral part of this present constitution and of Beninese law and have a value superior to the internal law'. This is repeated in article 7, and article 40 imposes on the State a duty to teach its citizens about the constitution, the UDHR, the ACHPR and any other 'international instruments duly ratified and relative to human rights'. In fact, the ACHPR is attached as an annexure to the Beninese constitution. ${ }^{56}$ The most significant effect is given to international law by the Bill of Rights in the Angolan, Kenyan and South African constitutions. Several provisions in the Angolan constitution underscore the importance and relevance of international instruments in interpreting and applying the constitution but the two most important ones are articles 26 and $27 .{ }^{57}$ In the Kenyan constitution, article 2(5) provides that 'the general rules of international law shall form part of the law of Kenya', and 2(6) that 'any treaty or convention ratified by Kenya shall form part of the law of Kenya under this constitution'. To a similar effect but perhaps less far-reaching is section 39(1) of the South African constitution.

Many other African constitutions also expressly incorporate some international human rights instruments. ${ }^{58}$ The question whether in the absence of an explicit or implicit authorisation, it is legitimate for a court to refer to or invoke international human rights instruments or rely on comparative law is quite controversial and

55 Sixty-seven out of the 244 articles in the constitution (that is 27.45 per cent) are in the Bill of Rights as compared with 39 articles out of 264 articles in Kenya's constitution (14.77 per cent) and 32 sections out 243 sections in the South African constitution (13.16 per cent).

56 In fact, Benin is one of the few countries in Africa that has expressly incorporated the UDHR and the ACHPR into its domestic law.

57 Other provisions that make express reference to the applicability of international law are articles 12 and 13.

58 See for example article 17(3) of the constitution of Cape Verde of 1999 and section 11(2) of the Malawi constitution of 1994. 
has provoked a lot of debate. ${ }^{59}$ Nevertheless, it can be argued that in the globalised world of today, it would be self-defeating and possibly a dereliction of duty for a judge to completely ignore legal developments in the rest of the world and their actual or potential implications on national law simply because there is no express or implied authorisation to do this in the constitution. The fundamental values that underpin modern social security law are now universal. While there may be differences, both formal and substantive in approach and implementation, it is clear that there are many areas of convergence and considerable scope for cross-systemic borrowing. The significance of the emerging trend towards the recognition of the applicability of international human rights instruments in the recent constitutions of countries such as Angola and Kenya is that this expands the scope of human rights that can be invoked under the constitution as well as giving the courts the power to adopt good practices from other jurisdictions. Nevertheless, it is now necessary to see how one of the best examples of a constitutionally entrenched social security rights system has operated in practice.

\section{IMPACT OF THE CONSTITUTIONALISATION OF THE RIGHT TO SOCIAL SECURITY IN AFRICA - THE SOUTH AFRICAN EXPERIENCE AND LESSONS FOR THE FUTURE}

This section will look in some depth at the constitutional framework for dealing with social security provided under the South African constitution and briefly discuss how the courts have interpreted this. This will form the basis for an assessment of the future prospects of an enforceable right to social security in Africa as a whole.

\section{A. The South African approach}

South Africa presently provides the most effective constitutional basis for the recognition and enforcement of the right to social security. Section 27 recognises the general right to social security but goes further to specify other specific rights that come within this general right. It states as follows:

(1) Everyone has the right to have access to -

(a) health care services, including reproductive health care;

(b) sufficient food and water; and

(c) social security, including, if they are unable to support themselves and their dependants, appropriate social assistance.

(2) The state must take reasonable legislative and other measures, within its available resources, to achieve the progressive realisation of each of these rights.

(3) No one may be refused emergency medical treatment.

59 See the discussion by N. J. Udombana, 'Interpreting Rights Globally: Courts and Constitutional Rights in Emerging Democracies', 5 African Human Rights Law Journal (2005): 64-9. 
Besides this right to health care, food, water and security, the constitution goes further to recognise a right to a clean environment which is conducive to health and wellbeing, ${ }^{60}$ a right to housing, ${ }^{61}$ and a right to education. ${ }^{62}$

For many decades, the main issue about socio-economic rights, of which the right to social security is a typical example, was their justiciability. ${ }^{63}$ As far as South Africa is concerned, the debate about the justiciability of socio-economic rights was laid to rest very early in the life of the new constitutional dispensation. In the First Certification judgment, the Constitutional Court said:

It is true that the inclusion of [socio-economic] rights may result in courts making orders, which have direct implications for budgetary matters. However, even when a court enforces civil and political rights such as equality, freedom of speech and the right to a fair trial, the order it makes will often have such implications ... The fact that [socio-economic] rights will almost inevitably give rise to such implications does not seem to be a bar to their justiciability. At the very minimum [socio-economic] rights can negatively be protected from improper invasions. ${ }^{64}$

In a number of early cases involving socio-economic rights in general, with many of these touching on aspects of social security rights, the South African Constitutional Court laid down a solid foundation for a justiciable system of socio-economic rights in the country. The landmark case in this respect is the Government of the Republic of South Africa v Grootboom. ${ }^{65}$ The case involved 900 respondents (390 adults and 510 children) who were living in deplorable cold and wet conditions in an informal settlement and had been evicted from low-cost housing land which they had occupied illegally. They were eventually left homeless. They applied to the High Court relying on sections 26 and $28(1)$ (c) of the constitution for an order requiring the government to provide them with alternative accommodation until such time that they could obtain adequate housing and shelter. The High Court relying on the suffering of the children and the 'immediacy' of the language in which the children's rights were couched in section 28(1)(c) of the constitution, ordered the provision of emergency shelter to the children and their parents. The State appealed to the Constitutional Court, arguing that it had a logical plan for the provision of housing in an orderly and

60 See section 24 of the constitution.

61 See section 26 of the constitution.

62 See section 29 of the constitution.

63 See for example E. W. Vierdag, 'The Legal Nature of the Rights Granted by the International Covenant on Economic, Social and Cultural Rights', 9 Netherlands Yearbook of International Law (1978): 69-105; Tomasveski, 'Justiciability of ESC Rights', supra note 43; M. Craven, 'The Justiciability of Economic, Social and Cultural Rights', in R. Burchill, D. Harris and A. Owers (eds), Economic, Social and Cultural Rights: Their Implications in UK Law, University of Nottingham (1999); and Tushnet, 'Social Welfare Rights and the Forms of Judicial Review', supra note 43.

64 Ex parte Chairperson of the Constitutional Assembly: In Re Certification of the Constitution of the Republic of South Africa 1996, 1996 (10) BCLR 1169 (CC).

652000 (11) BCLR 1169 (CC). 
systematic manner and that the effect of the High Court order would disrupt the plans through privileging certain groups over those patiently waiting on a housing list and entail expenditure of scarce resources. In a unanimous decision, the Constitutional Court, while acknowledging the difficulties of the situation, pointed to the absence of mechanisms for dealing with the emergency needs of those in dire straits as a flaw in the plans and confirmed the order. It noted that the constitution obliges the State to act positively to ameliorate the plight of the hundreds of thousands of people living in deplorable conditions throughout the country. Accordingly, the State is required to provide access to housing, health care, sufficient food and water, and social security to those unable to support themselves and their dependants. The court emphasised that neither section 26 nor section 28(1)(c) of the constitution gave any of the respondents the right to claim shelter from the State immediately. It then pointed out that the programme in place fell far short of the obligations imposed upon the State by section 26 of the constitution. Another very significant case is that of Minister of Health v Treatment Action Group (TAC) (No. 2). ${ }^{66}$ The action was brought by an AIDS activist group that had been pressurising the government to accelerate the programme for the prevention of intrapartum transmission of HIV. The Minister of Health refused on the grounds that there were concerns about the safety and efficacy of nevirapine and she only authorised two pilot sites to be established in each province. This was despite the fact that nevirapine had been registered in 1998 in South Africa by the Medicines Control Council and recommended by the World Health Organization. The Minister insisted that government's concerns about the safety and efficacy of the drug required further trials to address issues such as the potential for drug resistance to nevirapine use and possible complications linked to breastfeeding. A Department of Health study had revealed that a national programme of providing this antiretroviral drug to every HIVpositive pregnant woman would save 14,000 babies at a cost of US $\$ 10.5$ million or just about US\$750 per child. The aim of the legal action was to compel the government to roll out a national programme to distribute the drug to all. Amongst the issues that the Constitutional Court had to decide was whether (1) the government was entitled to refuse to make nevirapine available to pregnant women who have HIV and who give birth in the public sector in order to prevent or reduce the transmission of HIV to their infants; and (2) the government was obliged as a matter of law to implement and set out timeframes for a national programme to prevent mother-to-child transmission of HIV, including voluntary counselling and testing, antiretroviral therapy, and the option of using formula milk for feeding. In a unanimous judgment, the Constitutional Court ordered the government to remove the restrictions preventing nevirapine from being made available for the purposes of reducing the risk of mother-to-child transmission of HIV at public hospitals. The Court declared that the policy of reducing the risk of motherto-child transmission of HIV as previously formulated and implemented by the government fell short of compliance with its constitutional obligations. Sections 
$27(1) \&(2)$ of the constitution required the government to devise and implement within its available resources a comprehensive and coordinated programme to realise progressively the rights of pregnant women and their newborn children to have access to health services to combat mother-to-child transmission of HIV. This programme had to be realised progressively within the government's available resources and had to include reasonable measures for counselling and testing pregnant women for HIV, counselling HIV-positive pregnant women on the options open to them to reduce the risk of mother-to-child transmission, and making appropriate treatment available to them for such purposes. The Court reiterated the point it had made in the Grootboom case, ${ }^{67}$ namely that section 27(1) of the constitution does not give rise to a self-standing and independent positive right enforceable irrespective of the considerations mentioned in section 27(2). Both of these sections had to be read as defining the scope of the positive obligations on the State to respect, protect, promote and fulfil such rights. ${ }^{68}$

The South African courts have pronounced on several other housing rightsrelated cases since the two landmark cases of Grootboom and Treatment Action Campaign. ${ }^{69}$ Most of these have had to do with the issue of evictions. The government has tried to comply with its international and constitutional obligation to protect the right to housing by enacting a number of statutes, the most important of which are the Extension of Security of Tenure Act 621997 and the Prevention of Illegal Eviction from and Unlawful Occupation of Land Act 19 1998. A number of very important principles have emerged from some of the recent cases. In Port Elizabeth Municipality $v$ Various Occupiers ${ }^{70}$ the Constitutional Court, while finding that there is no 'unqualified constitutional duty' on state authorities to provide alternative housing to victims of evictions, said that 'a court should be reluctant to grant an eviction against relatively settled occupiers unless it is satisfied that a reasonable alternative is available, even if only as an interim measure pending access to housing in the formal housing program' ${ }^{71}$ And the Court pointed out that, '[t]he rights involved in s[ection] 26(3) [of the constitution] are defensive rather than affirmative. ${ }^{72}$ The key issue in the Port Elizabeth Municipality case and also in the later case of Occupiers of 51 Olivia Road and 197 Main Street, Johannesburg v The City of Johannesburg ${ }^{73}$ was the meaning of the State's obligation to 'meaningfully engage' with those

67 Supra note 65 , para. 38 .

68 Ibid., para. 39.

69 See for example Port Elizabeth Municipality v Various Occupiers 2004 (12) BCLR 1268(CC); City of Johannesburg v Rand Properties 2007 (6) BCLR 643 (SCA); Agrico Masjinerie v Swiers 2007 (10) BCLR 1111 (SCA); Barnett v Minister of Land Affairs 2007 (11) BCLR 1214 (SCA); Sailing Queen Investments v The Occupants La Colleen Court 2008 (6) BCLR 666(W); Occupiers of 51 Olivia Road and 197 Main Street, Johannesburg v The City of Johannesburg 2008 (3) SA 208; Residents of Joe Slovo Community, Western Cape v Thubelisha Homes 2009 (9) BCLR 847 (CC); and Abahlali baseMjondolo Movement SA v Premier of the Province of Kwazulu-Natal 2010 (2) BCLR 99(CC).

702005 (1) SA 217 (CC).

712004 (12) BCLR 1268 (CC), para. 28.

72 Ibid., para. 20.

73 Supra note 69. 
facing eviction to ascertain if they will be rendered homeless by an eviction. The Olivia Road case concerned the eviction of over 300 people occupying two dilapidated buildings in the inner city. The city council sought the eviction orders on the grounds that the buildings were unfit for human habitation, dangerous and unhygienic, and that evicting the occupiers would promote public health and safety as well as reverse inner-city decay. The Supreme Court of Appeal held that the deprivation of unsafe housing did not amount to an infringement of the right of access to adequate housing. Nevertheless, the eviction itself triggered an obligation on the City to provide emergency basic shelter to those who found themselves in a crisis situation. When the matter came before the Constitutional Court, an entirely different approach was adopted. The Court focused on the decision-making process of State institutions in dealing with such matters and encouraged the parties to engage in meaningful discussions. After negotiations between the parties, the Court endorsed a settlement agreement under which the city council undertook to provide two buildings in the inner city for the occupiers as well as provide them with interim services to the buildings. Although the Court's approach has been criticised on the grounds that it failed to substantively engage with the occupiers' attack on the constitutionality of the City's housing policy, the principle of meaningful engagement before evictions are carried out has become firmly established. ${ }^{74}$ In Abahlali baseMjondolo Movement SA v Premier of the Province of KwaZulu-Natal, ${ }^{75}$ the applicants challenged the constitutionality of section 16 of the KwaZulu-Natal Slums Act on the grounds that it violated section 26(2) of the constitution in three respects: (1) it precluded meaningful engagement between municipalities and unlawful occupiers; (2) it violated the principle that evictions should be a measure of last resort; and (3) it undermined the precarious tenure of unlawful occupiers, by mandating the institution of eviction proceedings and obliterating the established procedures under the Prevention of Illegal Eviction Act and the protection it afforded to unlawful occupiers. The Constitutional Court by a majority held that the notice mechanism set up in section $16^{76}$ was clearly irrational and overbroad and thus seriously invasive of the protections against arbitrary evictions contained in section 26(2) of the constitution. Perhaps more significant and far-reaching is the Constitutional Court's judgment in Residents of Joe Slovo Community, Western Cape $v$ Thubelisha Homes. ${ }^{77}$ The applicants were the residents of an informal settlement of about 20,000 shack-dwellers which was called Joe Slovo Informal Settlement. This settlement was targeted for reconstruction under a new government programme to eliminate all informal settlements. The residents were consulted about the new project and initially supported it but later

74 Even then, this too could become a purely procedural 'box to tick' process by government. See further 'A Review of Housing Policy and Development in South Africa since 1994' available at http://www.spii.org.za/agentfiles/434/file/Research/Review\%20of\%20the\%20Right $\% 20$ to\% 20Housing.pdf, p. 19 (accessed 28 October 2012).

752010 (2) BCLR 99 (CC).

76 It compelled an owner to evict unlawful occupiers.

772009 (9) BCLR 847 (CC). 
the people refused to move to a new settlement proposed to them to enable the construction work to commence. The government lodged an application under the Prevention of Illegal Eviction Act to have them evicted. The Court ruled that the applicants should not be required to move until alternative accommodation was provided. The order to vacate was conditional upon and subject to the applicants being relocated to temporary residential units that conformed to certain standards mutually agreed upon by the parties and approved by the Court. The judgment also specified that the parties were to engage meaningfully on a timetable for the move to the temporary site and that 70 per cent of the low-cost housing to be built at the site of the Joe Slovo Informal Settlement had to be made available to current and former residents of this settlement who had applied for and qualified for housing. One of the most interesting aspects of the judgment is that the Court specified in detail the quality and nature of the temporary housing to be provided, including the provision of services and facilities.

The compromise arrived at in the Joe Slovo case was never satisfactory. The Joe Slovo Informal Settlement is close to economic hubs where jobs and food can be accessed easily, children can walk to school and there is a cheap transport network. By contrast, the proposed new settlement was 15 kilometres out of town with no schools, transport or social facilities and was going to have a serious impact on household incomes and expenditure. When the Council realised that it was going to cost it more to relocate the residents than it would to upgrade Joe Slovo, it sought and obtained a Constitutional Court order on 24 August 2009 suspending the evictions. The government is now considering upgrading the settlement without displacing its occupants.

The most significant case in the last few years is that of Mazibuko v City of Johannesburg. ${ }^{78}$ Unlike the other cases on social security rights that had dealt with the right to housing, this one dealt with the question of right of access to water. It raised a number of critical questions. Is there a right to sufficient or adequate water? If so, what is this right's normative basis, its scope and content? ${ }^{79}$ It raised the critical question whether economic and social rights have a minimum legal content or a 'minimum core' as posited by the Committee on Economic, Social and Cultural Rights' General Comment No. 3 of 1990. In the case itself, certain residents from the suburb of Phiri in Soweto challenged the lawfulness of a project that the City of Johannesburg had introduced in order to address the problem of water losses and non-payment for water services in the Soweto area. The project involved amongst other things, installing pre-paid meters to charge consumers for use of water in excess of the 6 kilolitre per household monthly free basic water allowance. One of the main bases for challenging the City's

782010 (3) BCLR 239 (CC).

79 See P. Danchin, 'A Human Right to Water? The South African Constitutional Court's Decision in the Mazibuko Case', available at http://www.ejiltalk.org/a-human-right-to-water-the-southafrican-constitutional-court\%E2\%80\%99s-decision-in-the-mazibuko-case/ (accessed 28 October 2012); and M. Langford, “'Global Precedent” or "Reasonable No More:” The Mazibuko Case', available at http://www.jus.uio.no/smr/english/people/aca/malcolml/Case\%20comm\%207378\%20final.pdf (accessed 28 October 2012). 
plans was that it violated section 27(1) of the constitution which provides that '[e]veryone has the right to have access to ... (b) sufficient food and water.' The Constitutional Court concluded, in contrast to the High Court and the Supreme Court of Appeal, that it was not appropriate for a court to give a quantified content to what constituted 'sufficient water'; this was a matter best addressed by the government. The Court made it clear that the right of access to sufficient water did not require the State upon demand to provide every person with sufficient water without more. Rather, it required the State to take reasonable legislative and other measures progressively to realise the achievement of the right of access to sufficient water, within available resources. The argument that the Court should adopt a quantified standard in determining the content of the right to water and not merely its minimum content, the so-called minimum core concept, was as on two previous occasions ${ }^{80}$ rejected. The Court pointed out that fixing a quantified content might, in a rigid and counter-productive manner, prevent an analysis of the context. Further, that the concept of reasonableness places context at the centre of the enquiry and permits an assessment of context to determine whether a government programme is indeed reasonable. O'Regan J in reading the Court's unanimous judgment said:

ordinarily it is institutionally inappropriate for a court to determine precisely what the achievement of any particular social and economic right entails and what steps government should take to ensure the progressive realisation of the right. This is a matter, in the first place, for the legislature and executive, the institutions of government best placed to investigate social conditions in the light of available budgets and to determine what targets are achievable in relation to social and economic rights. Indeed, it is desirable as a matter of democratic accountability that they should do so for it is their programme and promises that are subjected to democratic popular choice. ${ }^{81}$

The Court made it clear that it could only intervene to enforce the positive obligations imposed by the constitution on the government if the latter took no steps to realise the rights or it adopted steps that were unreasonable, for example, by taking steps that made no provision for those who are desperately in need.

Finally, mention should also be made of the case of Cele v The South African Social Security Agency. ${ }^{82}$ In dealing with twenty-three applications arising from claims by applicants to be entitled to receive social security assistance grants, the Court noted that sections 27(1)(c) and 27(2) of the constitution embodied a constitutional right to social security. It then pointed out that although the

80 In the Grootboom case, supra note 65, para. 32, the Court had said, inter alia: 'It is not possible to determine the minimum threshold for the progressive realization of the right of access to adequate housing without first identifying the needs and opportunities for the enjoyment of such a right. These will vary according to factors such as income, unemployment, availability of land and poverty.' In Treatment Action Campaign No 2, supra note 66, para. 34, this again was rejected by the Court.

81 Supra note 78, para. 61-2.

822008 (7) BCLR 734(D). 
government had devoted 14.7 per cent of the national budget to providing social assistance grants to the poor, the needy and the disabled, the inability of the authorities to properly administer the scheme had led to a backlog of cases that have congested the court rolls and involved substantial costs to the taxpayer. The Court then issued a practice directive that was endorsed by other courts in the province designed to speed up the process of disposing of these cases.

\section{B. Lessons for the future}

Before considering what lessons can be learned from the South African experience insofar as the constitutionalisation of social security rights are concerned that can be of wider application to other African countries, a number of important caveats about the conclusions to be made are necessary.

The first point to note is that this analysis is limited to the provisions in the constitution. Some countries such as Botswana have no constitutional provisions providing a right to social security, yet the social security protection system in the country is one of the best in Africa. The government provides free education to its citizens, substantial assistance to the destitute and heavily subsidised health care for citizens. Second, no matter how constitutionally entrenched the right to social security may be, the fact that it is operating within a democracy, pseudodemocracy, transitional democracy or a dictatorship will matter. This was not taken into account in this analysis. Third, regardless of what the constitution states, a myriad of other equally important factors that are relevant but were not taken in account include the level and quality of political commitment, the availability of human and economic resources needed to be deployed in the task, the level of judicial activism, and a host of other administrative, educational and policy issues that have a significant impact on the quality of human rights protection in general. In spite of this, the constitutional entrenchment of the right to social security, like that of all other human rights, remains critical.

What the South African approach shows is that the foundation to an effective and a rights-based approach to the right to social security is the constitution. Many African constitutions do recognise the right to social security or many of the rights related to it. This in itself is not sufficient. A constitutionally entrenched right is only potentially effective if it is formulated in language that creates a sense of obligation on the State and is backed by a credible mechanism for ensuring that the State discharges its obligations. The entrenchment of the right to social security in South Africa is reinforced by the general principle stated in section 7(2) of the constitution that ' $[\mathrm{t}] \mathrm{he}$ State must respect, protect, promote and fulfil the rights in the Bill of Rights.' This imposes both a negative duty (the duty to respect) and positive duties (the duties to protect, promote and fulfil). The duty to respect requires the State to refrain from interfering with the enjoyment of social rights, and as the cases discussed above have shown, for example, by avoiding to violate the right to housing by arbitrary or forced evictions. ${ }^{83}$ The duty to protect requires 
the State to enact the relevant legislation and provide all the administrative and other measures needed to enforce these rights. The duty to promote enjoins the State to create a conducive environment for the exercise of these rights. And the duty to fulfil requires the State to take all appropriate legislative, administrative, budgetary, judicial and other measures needed to realise these rights.

Two important lessons can be learnt from this approach. First, in the absence of a clear constitutional provision such as sections 7(2) and 27 of the constitution, which define the nature of the obligation imposed on the State, there will be no standard by which to determine whether or not the State has fulfilled the obligation imposed on it. It is possible that the State may still perform many of the obligations that may arise under well-formulated constitutional social rights provisions, such as those under the South African constitution, with or without any such provisions imposing these duties on it. This is also possible where the constitutional provisions providing for social security are worded in obscure terms. In both instances, however, there is no guarantee that the State will do so or can be compelled to do so. Where the constitutional provision is obscurely worded, this will limit the ability of the judiciary to review and determine whether or not the State is discharging its duties. Second, the constitutional framework for complying with the right to social security does not impose any strict or specific standards, approaches or targets that the State should adopt as long as it acts reasonably. Starting with the Grootboom case,${ }^{84}$ the Constitutional Court pointed out that there are a wide range of measures that the State can adopt, but as long as the measure selected was reasonable and would lead to the progressive enjoyment of a particular right, the Courts will not interfere. Thus, in this case, the Court concluded that the plans in place that failed to provide relief for those in peril fell short of the obligations imposed by section 26 of the constitution. In the Mazibuko case, the Constitutional Court refused to determine the content of the right to social security by declining to quantify the amount of water sufficient for a dignified life under section 27 of the constitution. In general, in the different judgments, the South African courts have reviewed the different laws, policies, programmes and strategies put in place by the government to ensure that these are reasonable and appropriately directed towards achieving the social security goals for which they are designed. The cases illustrate how, because of the constitutional imperative, the courts can compel government to explain and justify its actions and even omissions ${ }^{85}$ It cannot act arbitrarily. In the Treatment Action Campaign case ${ }^{86}$ the Constitutional Court after pointing out that 'the courts are ill-suited to adjudicate upon issues where Court orders could have multiple social and economic consequences for the community', proceeded to point out that the constitution contemplated a more restrained and focused role for the courts. This was essentially to 'require the State to take measures to meet its constitutional obligations and to subject the reasonableness of these measures to evaluation' ${ }^{87}$

84 Supra note 65, para. 41.

85 See O'Regan J, in the Mazibuko case, supra note 78, para. 160-1.

86 Supra note 66, para. 34.

87 Ibid. 
In avoiding setting or defining any standards by which to assess the government's implementation approach and basing its evaluation on reasonableness, a number of criteria have emerged from the decided cases in determining whether or not the reasonableness standard has been met. These are:

- the social, economic and historical context of the deficiencies in the system the measures aimed to address;

- the institutional capacity provided to implement the programme adopted. Have the necessary tasks and responsibilities needed to implement the programme been properly allocated?;

- the balance in the programme and whether it is flexible and allows for review and adjustments with time;

- the inclusiveness of the programme;

- whether it ensures that the basic needs of those in dire need have been taken into account;

- whether it aims to benefit as large a number of people as possible. ${ }^{88}$

The international perspective given by the South African constitution as well as that of other countries such as Angola, Benin and Kenya cannot be ignored. As noted above, these constitutions allow the courts in interpreting the constitution to look at both foreign law and international law. Thus, for example, the South African courts in interpreting the concept of progressive realisation of social security rights have repeatedly rejected the 'minimum core obligation' that was endorsed by the UN Committee on Economic, Social and Cultural Rights. The important point to note here, however, is the potential benefits to clarifying, updating and modernising social security law that could result from the process of cross-fertilisation that comes from looking at and borrowing from the good practices of international and national courts abroad. One of the leading South African examples of this process of reinforcing national human rights standards by borrowing from other national and international courts is the case of $S v$ Makwanyane..$^{89}$ Before declaring that the death penalty was unconstitutional for being a form of cruel and inhumane treatment, the Court reviewed and cited more than 100 decisions from courts in the US, Canada, Hungary, India, the European Court of Human Rights as well as the UN Committee on Human Rights. ${ }^{90}$ In adopting this approach, Chaskalson $\mathrm{P}$ said:

International agreements and customary international law accordingly provide a framework within which [the Bill of Rights] can be

88 See Committee of Inquiry into a Comprehensive System of Social Security for South Africa, 'Approach to a Comprehensive Social Security Provisioning', in Transforming the Present-Protecting the Future, (2002), available at http://www.cdhaarmann.com/Publications/ Taylor\%20report.pdf (accessed 28 October 2012).

8919953 SA 391 (CC).

90 In Minister of Health v Treatment Action Group (TAC) (No. 2), 2002 (5) SA 721 (CC), the Constitutional Court went even further than this when it looked at a detailed comment by the UN Committee on Economic, Social and Cultural Rights in interpreting section 27 of the constitution. Although it did not adopt all of the comments, it was certainly influenced by this. For a more recent example see O'Regan J in the Mazibuko case, supra note 78, para. 40, note 31. 
evaluated and understood, and for that purpose, decisions of tribunals dealing with comparable instruments, such as the United Nations Committee on Human Rights, the Inter-American Commission on Human Rights, the Inter-American Court of Human Rights, the European Commission on Human Rights, and the European Court of Human Rights, and in appropriate cases, reports of specialised agencies such as the International Labour Organisation, may provide guidance as to the correct interpretation of particular provisions of [the Bill of Rights]. ${ }^{91}$

The significance of the emerging trend towards the recognition of the applicability of international human rights instruments in the recent constitutions of countries such as Angola and Kenya is that this expands the scope of human rights that can be invoked under modern constitutions as well as giving the courts the power to adopt good practices from other jurisdictions as the South African courts have done. This provides enormous possibilities for enriching national constitutional law through the process of judicial dialogue.

Another innovation of the South African constitution is that it also provides citizens with a remedy not only when the authorities violate or threaten to violate the constitution but also where the alleged 'violation' consists of a failure to fulfil a constitutional obligation. The potential benefits of this remedy are yet to be explored in the courts.

Finally, the South African cases show that all the rights associated with social security must also be protected. These include, for example, the right to adequate housing, the right to basic healthcare services, the right to sufficient food and water, the right to education, and the right of children, the old and destitute to basic nutrition, shelter and social services. The obligation on the State is not that it should become a charity that distributes money or resources to individuals, but rather that it should set up a reasonable system for dealing with the most vulnerable groups in society.

\section{CONCLUSION}

The social security systems in most African countries have evolved in a haphazard manner by default rather than design. One analysis has painted a gloomy picture about the future and suggested that the prospects for feasible social security systems in Sub-Saharan Africa are not encouraging. ${ }^{92}$ It is certainly true that devising a comprehensive social security system at a time of economic crisis like this, which will tackle the huge problems of poverty, disease, unemployment and other forms of deprivation that afflict many people, especially the vulnerable on the continent, will remain a major challenge. This is compounded by the fact that more than 70 per cent of African workers are in the informal sector and therefore out of reach of the social security system. Besides this, the continuing economic

91 Supra note 89 , para. 35.

92 Tostensen, 'Feasible Social Security Systems in Africa', supra note 11, p. 6. 
crisis has caused the informal social security systems which were held together by factors such as ties of kinship, ethnicity and friendship to fall apart as people struggle just to find enough to get by on.

It is the main contention of this paper that a solid constitutional framework that provides a right of social security in a form that compels the State to act is imperative. This is certainly not a guarantee that things will not go wrong for even South Africa with its reasonably effective constitutional framework is unable to ensure that 60 per cent of the poor get social security transfers. ${ }^{93}$ Nevertheless, it is an important starting point.

The new era of human rights protection, democracy and constitutionalism will only make sense and have meaning for the ordinary citizens when the constitution is seen to address in a meaningful and effective way the pressing issues of poverty, access to health care and other forms of social security needs that directly address the concerns of the poor and needy and also tries to close the ever widening gap between the rich and the poor. No region of the world presently endures the severe disparities between people's rights and their realisation that occurs in Africa. The hope is that constitutionally entrenched rights within the framework of a legally enforceable Bill of Rights will bring pressure to bear on African governments to deal with the growing social security needs. A rights-based approach to social security is more likely to be effective than an approach that allows the State to act on the basis of compassion or humanitarianism. It will also enable states to comply with the numerous international and regional frameworks that many of them have ratified. 